\title{
The Value of Cytokeratin 5/6, p63 and Thyroid Transcription Factor-1 in Adenocarcinoma, Squamous Cell Carcinoma and Non-Small-Cell Lung Cancer of the Lung
}

\section{Akciğerin Adenokarsinom, Skuamöz Hücreli Karsinom ve Küçük Hücreli Dışı Akciğer Kanserlerinde Sitokeratin 5/6, p63 ve TTF-1'in Değeri}

\author{
Asuman ARGON' ${ }^{1}$, Deniz NART ${ }^{2}$, Ali VERAL ${ }^{2}$ \\ 'Department of Medical Pathology, İmir Bozyaka Education and Research Hospital , IZMIR, TURKEY, \\ ${ }^{2}$ Department of Pathology, Ege University Faculty of Medicine, IZMIR, TURKEY
}

\section{ABSTRACT}

Objective: It is now important to distinguish between adenocarcinoma and squamous cell carcinoma of the lung because of target-specific treatments. Our study aimed to study the efficiency of Thyroid Transcription Factor-1 (TTF-1), cytokeratin 5/6 (CK5/6) and p63 in distinguishing between adenocarcinoma and squamous cell carcinoma and to study the contribution of these markers to the diagnosis in non-small cell lung cancer.

Material and Method: Immunohistochemically, TTF-1, CK 5/6 and p63 were used in 72 cases of squamous cell carcinoma, 19 cases of adenocarcinoma, and 29 cases of non-small cell lung cancer whose final diagnosis was decided with the subsequent resection material. The specificity, sensitivity, and positive and negative predictive value were calculated for each marker.

Results: TTF-1 positivity was seen in none of the 72 squamous cell carcinomas but in all of 19 adenocarcinoma cases. CK5/6 negativity was seen in all cases of adenocarcinoma and in two cases of squamous cell carcinoma. p63 was positive in all squamous cell carcinomas and in 4 adenocarcinomas. Cytokeratin 5/6, p63 positivity and TTF-1 negativity were observed in 17 non-small cell lung cancers whose final diagnosis was squamous cell carcinoma. None of the 12 non-small cell lung cancers whose final diagnosis was adenocarcinoma exhibited positive staining for CK5/6. However, p63 staining was not seen in the biopsy but was focal in the surgical specimen in one case. All the 12 non-small cell lung cancers whose certain diagnosis was adenocarcinoma were positive for TTF-1. TTF-1, CK 5/6 and p63 seem to be useful for differentiating adenocarcinoma from squamous cell carcinoma with $100 \%$ specificity, $100 \%$ sensitivity and $100 \%$ specificity, $97 \%$ sensitivity and $87 \%$ specificity, and $100 \%$ sensitivity, respectively.

Conclusion: We concluded that TTF-1 is a reliable marker for subtyping lung cancer. Different staining patterns can be seen with CK5/6 and p63; however, if they are used together with TTF- 1 and interpreted correctly, they can be of help for the final diagnosis even in cases in which the morphology is unclear.

Key Words: Adenocarcinoma, Squamous cell carcinoma, Immunohistochemistry, Lung cancer

(Turk Patoloji Derg 2015, 31:81-88)

Received : 31.07.2014 Accepted : 07.01.2015

\section{ÖZ}

Amaç: Günümüzde, hedefe yönelik tedaviler nedeniyle, akciğerin skuamöz hücreli karsinomunun adenokarsinomundan ayrımı çok önemlidir. Çalışmada, skuamöz hücreli karsinom ile adenokarsinomun ayrımında, Tiroid Transkripsiyon Faktör-1 (TTF-1), sitokeratin 5/6 (SK5/6) ve p63 kullanımının etkinliğinin ve bu belirteçlerin küçük hücreli dışı akciğer karsinomunun tanısına katkısı araştırıldı.

Gereç ve Yöntem: İmmunhistokimyasal olarak; 72 skuamöz hücreli karsinom, 19 adenokarsinom ve 29 küçük hücreli dışı akciğer karsinom (kesin tanısı rezeksiyon materyalinde verilen) olgusunda, TTF-1, SK5/6 ve p63 kullanılmıştır. Her belirteç için duyarlılık, özgüllük, pozitif ve negatif prediktif değer hesaplanmıştır.

Bulgular: TTF-1 pozitifliği, 19 adenokarsinom olgusunun tersine, 72 skuamözhücreli karsinom olgusunun hiçbirindeizlenmemiştir. CK5/6 negatifliği tüm adenokarsinomlarda ve 2 skuamöz hücreli karsinom olgusunda izlenmiştir. p63, tüm skuamöz hücreli karsinomlarda ve 4 adenokarsinom olgusunda pozitiftir.Son tanısı skuamöz hücreli karsinom olan 17 küçük hücreli dışı akciğer karsinom olgusunda, SK5/6 ve p63 pozitif, TTF-1 negatiftir. Son tanıs1 adenokarsinom olan 12 küçük hücreli dişı akciğer karsinom olgusunun hiçbirinde SK5/6 ile pozitiflik saptanmamıștır. Ancak, birinde p63 ile biyopside boyanma izlenmezken, rezeksiyon materyalinde fokal pozitiflik saptanmıştır. Son tanısı adenokarsinom olan 12 küçük hücreli dışı akciğer karsinom olgusunda TTF-1 pozitiftir. TTF-1, SK5/6, p63, adenokarsinomu skuamöz hücreli karsinomdan ayırmada, sırasıyla \%100 özgüllük ve duyarlılık, \%100 özgüllük, \%97 duyarlılık ve \%87 özgüllük, \%100 duyarlılık ile kullanışlı görünmektedir.

Sonuç: Çalışmada, akciğer kanserlerinin alt tiplendirmesinde TTF-1 güvenilir bir belirteç olarak bulunmuştur. SK5/6 ve p63 ile değişik boyanma paternleri izlenebilir, fakat eğer TTF-1 ile birlikte kullanılır ve doğru yorumlanırsa, bu belirteçler morfolojinin açık olmadığı olgularda bile kesin tanıya yardımcı olabilir.

Anahtar Sözcükler: Adenokarsinom, Skuamöz hücreli karsinom, İmmünhistokimya, Akciğer kanseri

Correspondence: Asuman ARGON

İzmir Bozyaka Eğitim ve Araştırma Hastanesi, Tibbi Patoloji Kliniği,

35300 Karabağlar, İzmir, TURKEY

E-mail: asumanargon@gmail.com Phone: +90 2322505050 


\section{INTRODUCTION}

Lung cancer is the number one cause of cancer-related mortality in men and women worldwide (1). Various histological types of lung cancer have been described. Historically, lung cancers were divided into two major groups as small-cell lung cancer and non-small-cell lung cancer (NSCLC) (2). Adenocarcinoma (AC), squamous cell carcinoma (SCC) and large cell carcinoma are the most common types of NSCLC (3). It is important to distinguish between AC and SCC because effectiveness of target-specific treatments (such as monoclonal antibody inhibitor of vascular endothelial growth factor (VEGF) and epidermal growth factor receptors-tyrosine kinase inhibitors) is different for AC and SCC. For example, bevacizumab, a VEGF drug/inhibitor, is an important drug in the treatment of some ACs. However, when it is used for SCC, it may cause life-threatening hemorrhage $(3,4)$. When the pulmonary carcinomas are classified, their histological features are considered first. However, morphology alone may not be enough in some cases due to small biopsies, poor differentiation, artifacts, and the heterogeneity of the tumor $(5,6)$. Immunohistochemistry (IHC) and gene expression profiling have been studied to solve this problem, but usually immunohistochemistry is the most practical solution $(6,7,8)$.

Our study aimed to study the efficiency of Thyroid Transcription Factor-1 (TTF-1), cytokeratin 5/6 (CK5/6) and p63 in distinguishing between AC and SCC and to study the contribution of these markers to the diagnosis in NSCLC.

\section{MATERIALS and METHODS}

\section{Study Design and Specimen Characteristics}

Malignant lung specimens were retrieved between December 2008- December 2010, using an electronic database. Nonepithelial tumors, metastatic tumors, large cell carcinoma and small cell lung carcinomas were excluded. All the tumor slides stained with Hematoxylin and Eosin (H\&E) of the 175 specimens were reviewed by three pathologists, at least one of whom was a pulmonary pathologist. In biopsy specimens, the tumors were classified as SCC if they contained intercellular bridges and/or showed keratinization, and as AC if they clearly showed gland formation or mucin production. Extracellular mucin or a goblet cell-like appearance were considered as mucin production. To be certain about the tumor classification for NSCLC in biopsy, we required a surgical specimen as the gold standard for diagnosis. Three pathologists blinded to the immunohistochemical findings subtyped the resected tumors on the basis of H\&E slides according to the World Health Organization classification of lung tumors (9) and they changed the first diagnosis if necessary.

The cases were included in the study (1) if the biopsy had typical AC morphology (2), if the biopsy had typical SCC morphology (3) when the pathologists agreed on the diagnosis of NSCLC and if the tumor was subsequently resected at our institution (4) if blocks from biopsy and lobectomy specimens were available for immunohistochemical study. Fifty-five of the 175 cases did not meet these criteria and were excluded. The remaining 120 cases were included in this study. Using morphological evaluation, the cases were divided into four groups: AC, SCC, NSCLC-SCC whose final diagnosis was SCC in the subsequent resection material, and NSCLC-AC whose final diagnosis was $\mathrm{AC}$ in the subsequent resection material.

\section{Immunohistochemistry}

Four-micron-thick sections were obtained for IHC investigation. Immunohistochemistry was performed by a standard protocol on a Ventana Discovery XT automated stainer (Ventana Medical Systems, Tucson, AZ, USA). Only primary antibodies, cytokeratin 5/6 (Clone D5/16B4, Dako, 1:200 dilution), p63 (Clone 4A4, Dako, 1:700 dilution) and TTF-1 (Clone SPT24, NovoCastra, 1:50 dilution) were added manually and incubated in $37^{\circ} \mathrm{C}$ for 32 minutes. Pneumocytes were considered as internal controls for TTF1 positivity, and bronchial basal cells for p63 and CK5/6 positivity.

Immunohistochemically, cytoplasmic staining was considered positive for cytokeratin $5 / 6$ and nuclear staining was considered positive for TTF- 1 and p63. All the areas of biopsy materials and at least 10 high power fields in tumor surgical materials were evaluated and the mean percentage of the positive tumor cells was determined. The staining rate was divided into four categories as follows: $0,<1 \% ; 1+$, $1-33 \% ; 2+, 34-66 \% ; 3+,>66 \%$. Intensity of staining was graded as negative ( 0 , no reactivity); weak $(1+$, less than normal cells); moderate $(2+$, same as normal cells); and strong $(3+$, stronger than normal cells) $(9,10)$. When the staining was heterogeneous, the prominent pattern became the basis. The demographic features (age, gender) were obtained from the hospital archive system. For NSCLC cases, we also assessed whether immunohistochemical staining on biopsies correlated with staining on the subsequent surgical specimens as lung cancers are known to show morphologic heterogeneity in different areas of the same tumor. 


\section{Data Analysis}

The statistical analyses were performed with SPSS software, version 20.0. The specificity, sensitivity, positive predictive value and negative predictive value were calculated for each marker. In addition, the relationship between the staining on biopsy and resection materials was analyzed using Pearson Chi-Square test, Chi-Square test and Fisher's Exact Test. p values of $\leq 0.05$ were considered statistically significant.

\section{RESULTS}

There were $104(86.7 \%)$ males and 16 (13.3\%) females included in the study with a mean age of $62.30 \pm 8.74$ and a median age of 62.00 (Min: 37, max: 82 ) years. Histologically,
$72(60.0 \%)$ cases were SCC and $19(15.8 \%)$ cases AC. The remaining 29 cases were NSCLC, 17 (14.2\%) of which were NSCLC-SCC and 12 (10.0\%) were NSCLC-AC. The results of immunohistochemical staining for each histological subtype of carcinoma are summarized in Table I. The relationship between the stainings on biopsy and resection materials and $\mathrm{p}$ values are shown in Table II.

Cytokeratin 5/6: Of the 72 SCC cases, 56 had 3+ staining, 4 had $2+$ and 10 had $1+$. CK5/6 negativity was encountered in two SCC cases that had TTF-1(-)/p63(+) (Figure 1A-C). In the cases that stained positive, intensity of staining was strong in 54 cases, moderate in 13 cases and weak in 3 cases. However, no staining was seen in any of the 19 AC cases.

Table I: The results of immunohistochemical staining for each histological subtype of carcinoma and the specificity, sensitivity, positive predictive value and negative predictive value

\begin{tabular}{|c|c|c|c|c|c|c|c|c|c|c|c|c|}
\hline & \multicolumn{4}{|c|}{ Cytokeratin 5/6 } & \multicolumn{4}{|c|}{ p63 } & \multicolumn{4}{|c|}{ TTF-1 } \\
\hline & \multicolumn{3}{|c|}{ Positive (n) } & \multirow{2}{*}{$\begin{array}{c}\text { Negative } \\
\text { (n) }\end{array}$} & \multicolumn{3}{|c|}{ Positive (n) } & \multirow{2}{*}{$\begin{array}{c}\text { Negative } \\
\text { (n) }\end{array}$} & \multicolumn{3}{|c|}{ Positive (n) } & \multirow{2}{*}{$\begin{array}{c}\text { Negative } \\
\text { (n) }\end{array}$} \\
\hline & $1+$ & $2+$ & $3+$ & & $1+$ & $2+$ & $3+$ & & $1+$ & $2+$ & $3+$ & \\
\hline SCC & 10 & 4 & 56 & 2 & 0 & 1 & 71 & 0 & 0 & 0 & 0 & 72 \\
\hline $\mathrm{AC}$ & 0 & 0 & 0 & 19 & 2 & 1 & 1 & 15 & 2 & 1 & 16 & 0 \\
\hline NSCLC-SCC & 0 & 6 & 11 & 0 & 0 & 1 & 16 & 0 & 0 & 0 & 0 & 17 \\
\hline NSCLC-AC & 0 & 0 & 0 & 12 & 0 & 0 & 0 & 12 & 0 & 0 & 12 & 0 \\
\hline
\end{tabular}

TTF-1: Thyroid Transcription Factor 1; AC: Adenocarcinoma; SCC: Squamous cell carcinoma

NSCLC-SCC: Non-small-cell lung cancer whose final diagnosis was SCC in their subsequent resection material

NSCLC-AC: Non-small-cell lung cancer whose final diagnosis was AC in their subsequent resection material.

Table II: The results of immunohistochemical staining for each histological subtype of carcinoma in biopsy and resection material and the $\mathrm{p}$ value

\begin{tabular}{|c|c|c|c|c|c|c|c|c|c|c|c|c|}
\hline & \multicolumn{4}{|c|}{ Cytokeratin 5/6 } & \multicolumn{4}{|c|}{ p63 } & \multicolumn{4}{|c|}{ TTF-1 } \\
\hline & \multicolumn{3}{|c|}{ Positive (n) } & \multirow{2}{*}{$\begin{array}{l}\text { Negative } \\
\text { (n) }\end{array}$} & \multicolumn{3}{|c|}{ Positive (n) } & \multirow{2}{*}{$\begin{array}{l}\text { Negative } \\
\text { (n) }\end{array}$} & \multicolumn{3}{|c|}{ Positive (n) } & \multirow{2}{*}{$\begin{array}{c}\text { Negative } \\
\text { (n) }\end{array}$} \\
\hline & $1+$ & $2+$ & $3+$ & & $1+$ & $2+$ & $3+$ & & $1+$ & $2+$ & $3+$ & \\
\hline $\begin{array}{l}\text { NSCLC-SCC } \\
\text { biopsy }\end{array}$ & 0 & 6 & 11 & 0 & 0 & 1 & 16 & 0 & 0 & 0 & 0 & 17 \\
\hline $\begin{array}{l}\text { NSCLC-SCC } \\
\text { resection }\end{array}$ & 0 & 4 & 13 & 0 & 0 & 1 & 16 & 0 & 0 & 0 & 0 & 17 \\
\hline P value ${ }^{\star}$ & \multicolumn{4}{|c|}{0.50} & \multicolumn{4}{|c|}{-} & \multicolumn{4}{|c|}{-} \\
\hline $\begin{array}{l}\text { NSCLC-AC } \\
\text { biopsy }\end{array}$ & 0 & 0 & 0 & 12 & 0 & 0 & 0 & 12 & 0 & 0 & 12 & 0 \\
\hline $\begin{array}{l}\text { NSCLC-AC } \\
\text { resection }\end{array}$ & 0 & 0 & 0 & 12 & 1 & 0 & 0 & 11 & 0 & 0 & 12 & 0 \\
\hline P value ${ }^{*}$ & \multicolumn{4}{|c|}{-} & \multicolumn{4}{|c|}{1.00} & \multicolumn{4}{|c|}{-} \\
\hline
\end{tabular}

TTF-1: Thyroid Transcription Factor 1; AC: Adenocarcinoma; SCC: Squamous cell carcinoma

NSCLC-SCC biopsy: Biopsy of non-small-cell lung cancer whose final diagnosis was SCC in their subsequent resection material

NSCLC-AC biopsy: Biopsy of non-small-cell lung cancer whose final diagnosis was AC in their subsequent resection material.

*: The statistical analysis was not performed in condition where there was constant 


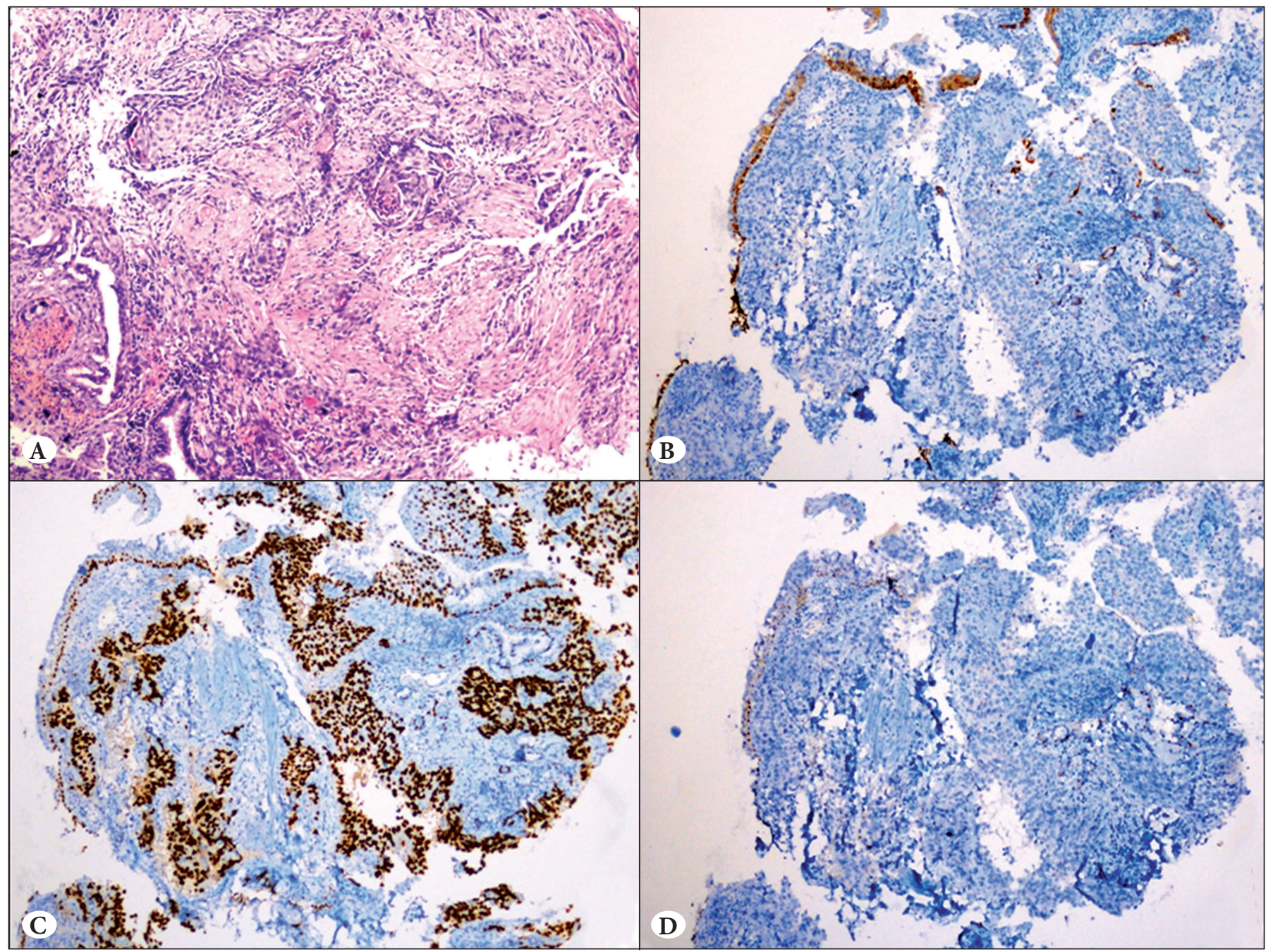

Figure 1: A) SCC case whose morphology is typical in biopsy (H\&E; x20), B) CK5/6 negativity (CK5/6; x10), C) p63 positivity (p63; x10), D) TTF-1 negativity (TTF-1; x10).

When focal staining was considered positive, the specificity, sensitivity, positive predictive value and negative predictive value were 1.000 (95\% Confidence Interval: 0.1000-1.0000), 0.978 (95\% Confidence Interval: 0. 9467-1.0000), 0.939 (95\% Confidence Interval: 0.8580-1.0000) and 1.000 (95\% Confidence Interval: 0.1000-1.0000), respectively.

Positive staining was observed in all of the 17 NSCLCSCC cases (Figure 2A-B). While the staining rate did not change in the biopsy and the surgical specimen in 15 of the 17 cases, it increased in the surgical specimen in the remaining 2 cases. No statistically significant difference was found between the staining rates of the biopsy and surgical specimens $(\mathrm{p}=0.500)$. None of the 12 NSCLC-AC cases exhibited positive staining either in biopsy or surgical specimens so no statistical calculations were performed.
When the staining intensity in the NSCLC-SCC cases and that in surgical specimens were compared, it did not change in 15 cases but it increased in the surgical specimens of 2 cases. In the NSCLC-SCC cases, the intensity of staining displayed no statistically significant difference between biopsy and surgical specimens $(\mathrm{p}=0.500)$.

p63: We observed 3+ staining in 71 of the 72 SCC cases and $2+$ staining in one. There was no staining in 15 of the $19 \mathrm{AC}$ cases. However, p63 positivity was observed in $4 \mathrm{AC}$ cases that had TTF-1(+)/ CK5/6 (-) (Figure 3A-D). Two cases had $1+$ staining. One of the remaining two had $2+$ staining and the other had $3+$ staining. Intensity of p63 staining was weak in 3 of the $4 \mathrm{AC}$ cases and it was moderate in one. When the focal staining was considered positive, the specificity, sensitivity, positive predictive value and negative predictive 
value were 0.871 (95\% Confidence Interval: $0.7530-1.0000$ ), 1.0000 (95\% Confidence Interval: 1.0000-1.0000), 1.000 (95\% Confidence Interval: 1.0000-1.0000) and 0.957 (95\% Confidence Interval: 0,9158-1.0000), respectively.

In all of the 17 NSCLC-SCC cases (Figure 2C), the staining rate and intensity were the same both in the NSCLC areas and surgical specimens so no statistical assessment was conducted. Eleven of the 12 NSCLC-AC had no staining both in biopsy and surgical specimens. In the other case, staining was not seen in the biopsy but $1+$ staining was seen in the surgical specimen. That finding was not found statistically significant $(\mathrm{p}=1.000)$.

TTF-1: TTF-1 staining was not seen in any of the 72 SCC cases while it was seen in all AC cases. In 16 of the AC cases, the staining was $3+$ but $2+$ in one of them and $1+$ in two of them. Staining intensity was strong in 17 cases whereas it was weak in one case. When the focal staining was considered positive, the specificity, sensitivity, positive predictive value and negative predictive value were 1.000 (95\% Confidence Interval: 1.0000-1.0000), 1.000 (95\% Confidence Interval: 1.0000-1.0000), 1.000 (95\% Confidence Interval: 1.00001.0000 ) and 1.000 (95\% Confidence Interval: 1.00001.0000), respectively.

In all of the 12 NSCLC-AC cases, the rate and intensity of staining in the NSCLC areas were the same as those in the surgical specimens. In all of the 17 NSCLC-SCC cases (Figure 2D), staining was seen in neither NSCLC areas nor surgical specimens. Since TTF-1 staining in NSCLC- SCC and NSCLC-AC was the same, no statistical analyses were performed.

In 29 NSCLC cases whose diagnosis was confirmed by the surgical specimen, no difference was found in the rate and

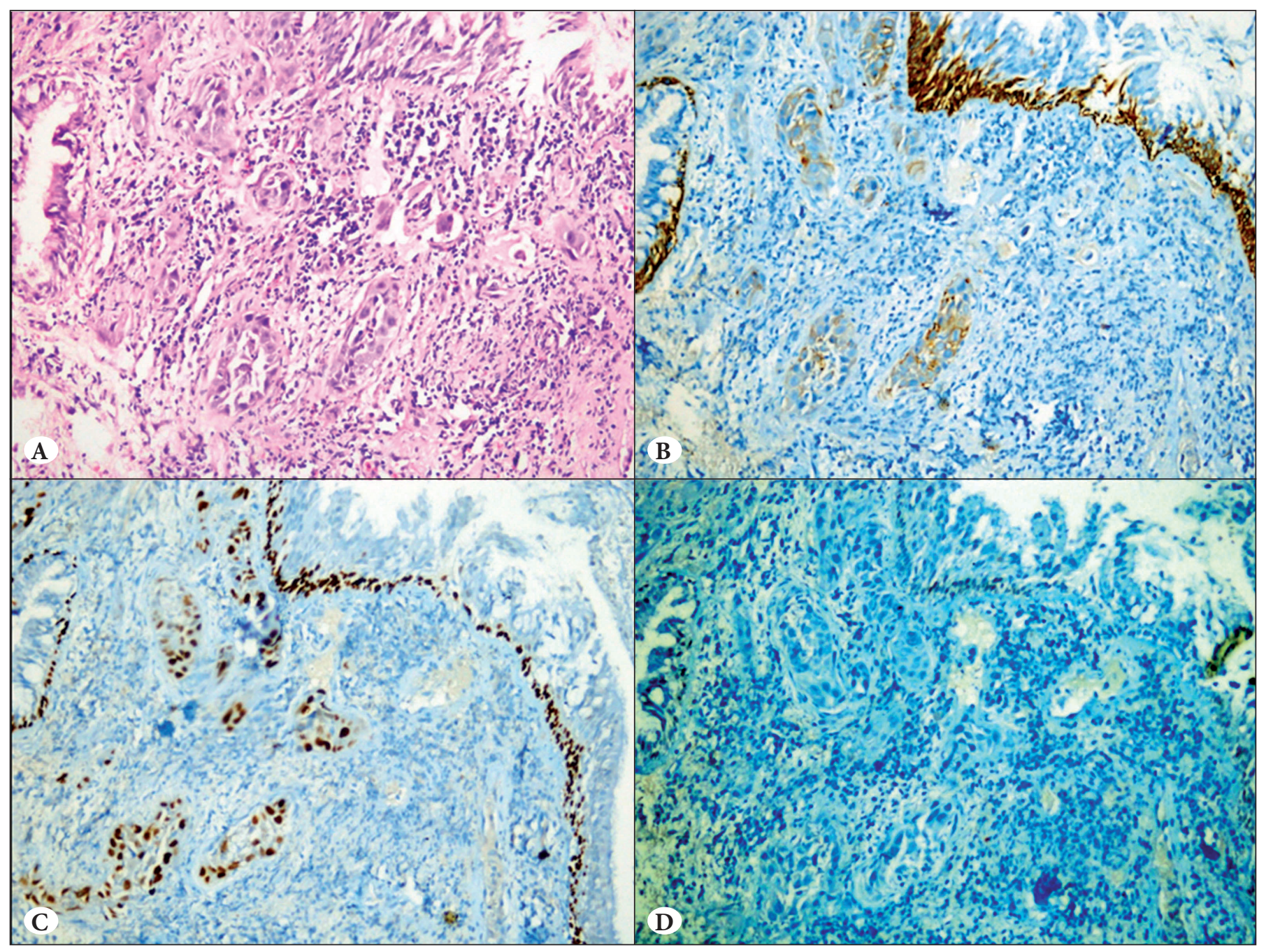

Figure 2: A) NSCLC case whose final diagnosis is SCC in its subsequent resection material (H\&E; x20), B) CK5/6 focal-weak positivity (CK5/6; x20), C) p63 positivity (p63; x20), D) TTF-1 negativity (TTF-1; x20). 


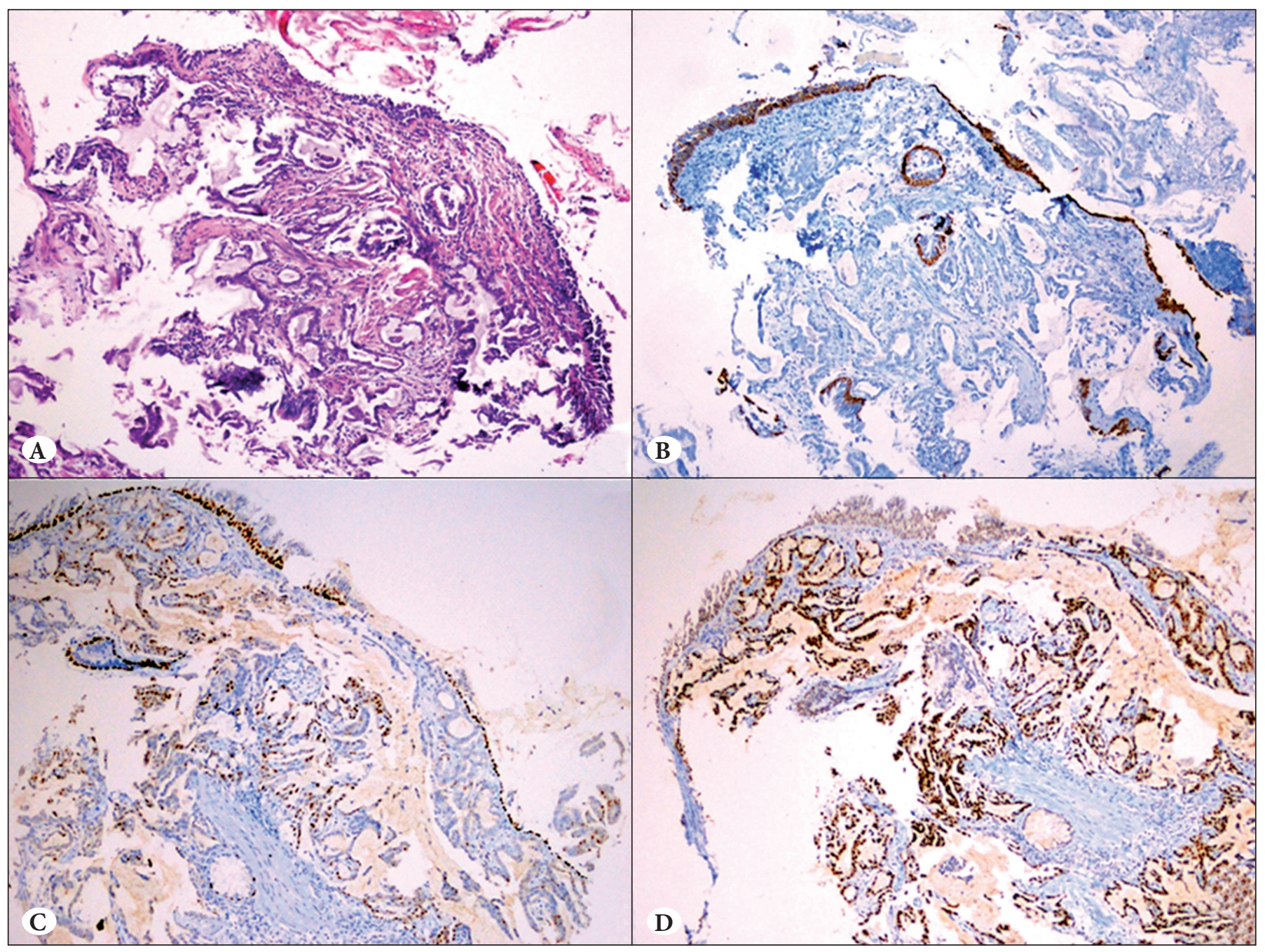

Figure 3: A) AC case whose morphology is typical in biopsy (H\&E; x10), B) CK5/6 negativity (CK5/6; x10), C) p63 positivity (p63; x10), D) TTF-1 positivity (TTF-1; x10).

intensity of staining in both biopsy and surgical specimens for all three immunohistochemical markers ( $p>0.050)$.

Statistically, no difference was found between the sensitivity of immunohistochemical markers $(\mathrm{p}=0.506)$ but the specificity of TTF- 1 and CK5/6 was higher than that of $\mathrm{p} 63(\mathrm{p}=0.001)$. The specificity, sensitivity, positive predictive value and negative predictive value for each immunohistochemical marker are shown in Table III.

\section{DISCUSSION}

With target-specific therapies, precise histologic subtyping of lung cancer is needed more than ever before. Morphological misdiagnosis is more common in biopsy because of more limited tissue than in surgical specimens (5). For accurate diagnosis, immunohistochemistry is usually employed in both surgical and biopsy $(10,12,13)$. The immunohistochemical use of CK5/6, TTF-1 and p63 together is recommended by the International Association for the Study of Lung Cancer/American Thoracic Society/ European Respiratory Society (14). Thyroid transcription factor 1 is an indication of the lung and thyroid origin. The high sensitivity and specificity of TTF-1 for pulmonary adenocarcinoma (AC) have been noted by earlier studies (13-15). Most studies dealt with the sensitivity and specificity of TTF-1 for AC of the lung. In a study conducted on a large series by Warth et al.(2), it was reported that TTF-1 positivity was seen in $87.7 \%$ of AC cases. However, in the studies conducted on a limited series, positivity went down to $70 \%$ (14). TTF-1 positivity was seen in all of the AC cases in our study while it was focal in three cases and weak in one. A few studies suggest that some squamous cell carcinomas (SCC) (3\% to $21 \%$ ) may be TTF-1 positive $(17,18,19)$. As already known, TTF-1 positivity is not an anticipated finding in SCC. If TTF-1 positivity exists in 
Table III: The specificity, sensitivity, positive predictive value and negative predictive value for each immunohistochemical marker

\begin{tabular}{|l|c|c|c|c|}
\hline & Cytokeratin 5/6 & p63 & TTF-1 & p value \\
\hline Specificity $^{\star}$ & $100 \%$ & $87.1 \%$ & $100 \%$ & 0.001 \\
\hline Sensitivity & $97.8 \%$ & $100 \%$ & $100 \%$ & 0.506 \\
\hline PPV $^{\star}$ & $100 \%$ & $95.7 \%$ & $100 \%$ & 0.144 \\
\hline NPV $^{\star}$ & $93.9 \%$ & $100 \%$ & $100 \%$ & 0.053 \\
\hline
\end{tabular}

TTF-1: Thyroid Transcription Factor 1 ; PPV: Positive predictive value ; NPV: Negative predictive value

*: When focal stainings are regarded as positive

SCC, it could be entrapped lung epithelium or solid AC may have been misinterpreted as SCC $(13,20)$. There was no staining in any SCC case in our study. Moreover, TTF1 positivity was observed in neither biopsy nor surgical specimen of non-small-cell lung cancer (NSCLC-SCC) cases. According to the results of our study, TTF-1 is the most reliable marker to distinguish between AC and SCC. Besides, TTF-1 positivity can be considered as a finding of $\mathrm{AC}$ differentiation even if it is focal and weak in the cases where histological differentiation is not clear.

The reported sensitivity of CK5/6 for pulmonary SCC ranges from $73 \%$ to $100 \%$ and the sensitivity of CK5/6 is reported to go down as there is a decrease in the tumor differentiation $(7,13,21)$. CK5/6 positivity was observed in 43 of 48 SCC cases in the study by Kim et al. (16), but in all 32 SCC cases in the study by Nicholson et al. (22). One of the reasons for the wide range of CK5/6 sensitivity can be the fact that some studies regard focal or weak staining as positive but others do not. In our study, no CK5/6 staining was detected in only two cases while $75 \%$ of SCC cases were diffuse and strong positive. All the NSCLC-SCC cases were CK5/6 positive but six of them were focal. In addition, the staining was diffuse in two surgical specimens but it was focal in their former biopsies. According to our findings, CK5/6 was a highly specific but not very sensitive marker in distinguishing between SCC and AC when focal and weak staining were considered to be positive. Additionally, CK5/6 positivity can be considered as a finding supporting SCC even if it is focal in the cases where histological differentiation is not clear.

The utility of $\mathrm{p} 63$ for the identification of lung SCCs is well-known, and its sensitivity ranges from $73 \%$ to $100 \%$ $(5,7,13)$. However, p63 specificity is not high because p63 can be stained focal and/or weak in some ACs $(12,13,16)$. In our study, p63 positivity was observed in $4 \mathrm{AC}$ cases which had TTF- $1(+) /$ CK5/6 (-). Staining was focal in three cases but diffuse in one. Nevertheless, intensity of staining was weak in the case that had diffuse staining like the other two cases that had focal staining. This finding is in agreement with the literature. All of the NSCLC-SCC in our study were positive for $\mathrm{p} 63$ and their staining rate and intensity were the same both in NSCLC areas and surgical specimens. None of the NSCLC-AC cases had staining except one, in which staining was not seen in the biopsy while focal (1-33\%) staining was seen in the surgical specimen. In a study contucted by Warth et al. (2), p63 positivity was seen in $16.3 \%$ of the histomorphologically unclear ACs and staining intensity was lower than in SCC. Our study suggests that an $\mathrm{AC}$ diagnosis can be made despite p63 positivity in some cases, as in the literature. If the p63 positivity is focal and weak or moderate, TTF-1 positivity and CK5/6 negativity are enough for AC diagnosis even if AC is not clear histomorphologically. In our study, SCC had CK5/6 negativity and AC had $\mathrm{p} 63$ positivity in a few cases. However, TTF-1 was positive in all the ACs and negative in all the SCCs. Although the specificity, sensitivity, PPV and NPV of TTF- 1 were $100 \%$, a statistically significant difference was found in only the specificity value due to the limited number of cases. Our results need to be supported by studies including large series.

Subtyping of NSCLCs is very important due to current treatment modalities. Immunohistochemistry can be used in subtyping of samples with limited tissue and cases in which the morphology is unclear. TTF-1, CK 5/6 and p63 are the markers that can be used for this purpose. Different staining patterns can be seen with CK5/6 and p63; however they can be of help for the final diagnosis even in the cases in which morphology is unclear, if they are used together with TTF-1 and interpreted correctly.

\section{Acknowledgments}

We gratefully acknowledge Hatice Uluer in the Department of Biostatistics and Medical Communication of Ege University for performing the statistical analyses. 


\section{REFERENCES}

1. Jemal A, Siegel R, Xu J, Ward E. Cancer statistics, 2010. CA Cancer J Clin. 2010;60:277-300.

2. Warth A, Muley T, Herpel E, Meister M, Herth FJ, Schirmacher P, Weichert W, Hoffmann H, Schnabel PA. Large-scale comparative analyses of immunomarkers for diagnostic subtyping of nonsmall-cell lung cancer biopsies. Histopathology. 2012;6:1017-25.

3. Whithaus K, Fukuoka J, Prihoda TJ, Jagirdar J. Evaluation of napsin A, cytokeratin 5/6, p63, and thyroid transcription factor 1 in adenocarcinoma versus squamous cell carcinoma of the lung. Arch Pathol Lab Med. 2012;136:155-62.

4. Gressett SM, Shah SR. Intricacies of bevacizumab-induced toxicities and their management. Ann Pharmacother. 2009;43:490-501.

5. Pelosi G, Rossi G, Bianchi F, Maisonneuve P, Galetta D, Sonzogni A, Veronesi G, Spaggiari L, Papotti M, Barbareschi M, Graziano P, Decensi A, Cavazza A, Viale G. Immunhistochemistry by means of widely agreed-upon markers (cytokeratins 5/6 and 7, p63, thyroid transcription factor-1, and vimentin) on small biopsies of non-small cell lung cancer effectively parallels the corresponding profiling and eventual diagnoses on surgical specimens. J Thorac Oncol. 2011;6:1039-49.

6. Rossi G, Pelosi G, Graziano P, Barbareschi M, Papotti M. A reevaluation of the clinical significance of histological subtyping of non--small-cell lung carcinoma: Diagnostic algorithms in the era of personalized treatments. Int J Surg Pathol. 2009;17:206-18.

7. Kargi A, Gurel D, Tuna B. The diagnostic value of TTF-1, CK5/6, and p63 immunostaining in classification of lung carcinomas. Appl Immunohistochem Mol Morphol 2007;15:415-20.

8. Noh S, Shim H. Optimal combination of immunohistochemical markers for subclassification of non-small cell lung carcinomas: A tissue microarray study of poorly differentiated areas. Lung Cancer 2012;76: 51-5.

9. World Health Organization classification of tumours. Pathology and genetics of tumours of the lung, pleura, thymus and heart. Travis WD, Brambilla E, Mqller-Hermelink HK, Harris CC, editors. Lyon7: IARC Press; 2004.

10. Fatima N, Cohen C, Lawson D, Siddiqui MT. TTF1 and napsin A double stain: A useful marker for diagnosing lung adenocarcinoma on fine-needle aspiration cell blocks. Cancer Cytopathol. 2011;119:127-33.

11. Rekhtman N, Ang DC, Sima CS, Travis WD, Moreira AL. Immunohistochemical algorithm for differentiation of lung adenocarcinoma and squamous cell carcinoma based on large series of whole-tissue sections with validation in small specimens. Mod Pathol. 2011;24:1348-59.

12. Conde E, Angulo B, Redondo P, Toldos O, García-García E, Suárez-Gauthier A, Rubio-Viqueira B, Marrón C, GarcíaLuján R, Sánchez-Céspedes M, López-Encuentra A, Paz-Ares L, López-Ríos F. The use of p63 immunohistochemistry for the identification of squamous cell carcinoma of the lung. PLoS One 2010;5:1-6.
13. Mukhopadhyay S, Katzenstein AL. Subclassification of nonsmall cell lung carcinomas lacking morphologic differentiation on biopsy specimen: Utility of an immunohistochemical panel containing TTF-1, napsin A, p63, and CK5/6. Am J Surg Pathol 2011;35:15-25.

14. Travis WD, Brambilla E, Noguchi M, Nicholson AG, Geisinger KR, Yatabe Y, Beer DG, Powell CA, Riely GJ, Van Schil PE, Garg K, Austin JH, Asamura H, Rusch VW, Hirsch FR, Scagliotti G, Mitsudomi T, Huber RM, Ishikawa Y, Jett J, Sanchez-Cespedes M, Sculier JP, Takahashi T, Tsuboi M, Vansteenkiste J, Wistuba I, Yang PC, Aberle D, Brambilla C, Flieder D, Franklin W, Gazdar A, Gould M, Hasleton P, Henderson D, Johnson B, Johnson D, Kerr K, Kuriyama K, Lee JS, Miller VA, Petersen I, Roggli V, Rosell R, Saijo N, Thunnissen E, Tsao M, Yankelewitz D. International association for the study of lung cancer/american thoracic society/european respiratory society international multidisciplinary classification of lung adenocarcinoma. J Thorac Oncol. 2011;6:244-85.

15. Loo PS, Thomas SC, Nicolson MC, Fyfe MN, Kerr KM. Subtyping of undifferentiated non-small cell carcinomas in bronchial biopsy specimens. J Thorac Oncol 2010;5:442-7.

16. Kim MJ, Shin HC, Shin KC, Ro JY. Best immunohistochemical panel in distinguishing adenocarcinoma from squamous cell carcinoma of lung: Tissue microarray assay in resected lung cancer specimens. Ann Diagn Pathol. 2013;17:85-90.

17. Chang YL, Lee YC, Liao WY, Wu CT. The utility and limitation of thyroid transcription factor-1 protein in primary and metastatic pulmonary neoplasms. Lung Cancer. 2004;44:149-57.

18. Jerome Marson V, Mazieres J, Groussard O, Garcia O, Berjaud J, Dahan M, Carles P, Daste G. Expression of TTF-1 and cytokeratins in primary and secondary epithelial lung tumours: Correlation with histological type and grade. Histopathology. 2004;45:125-34.

19. Tan D, Li Q, Deeb G, Ramnath N, Slocum HK, Brooks J, Cheney R, Wiseman S, Anderson T, Loewen G. Thyroid transcription factor-1 expression prevalence and its clinical implications in nonsmall cell lung cancer: A high-throughout tissue microarray and immunohistochemistry study. Hum Pathol. 2003;34:597604.

20. Monica V, Ceppi P, Righi L, Tavaglione V, Volante M, Pelosi G, Scagliotti GV, Papotti M. Desmocollin-3: A new marker of squamous differentiation in indifferentiated large-cell carcinoma of the lung. Mod Pathol. 2009;22:709-17.

21. Downey P, Cummins R, Moran M, Gulmann C. If it's not CK5/6 positive, TTF-1 negative it's not a squamous cell carcinoma of lung. APMIS. 2008;116:526-9.

22. Nicholson AG, Gonzalez D, Shah P, Pynegar MJ, Deshmukh M, Rice A, Popat S. Refining the diagnosis and EGFR status of nonsmall cell lung carcinoma in biopsy and cytologic material, using a panel of mucin staining, TTF-1, cytokeratin 5/6, and P63, and EGFR mutation analysis. J Thorac Oncol. 2010;5:436-41. 